\title{
Functional Judgment of Young Mexican Heterosexuals' Judgment towards Gay, Lesbian and Heterosexual Adoption
}

\author{
Karen Alejandra Garza-Figueroa ${ }^{1}$, Ernesto Octavio Lopez-Ramirez ${ }^{1}$, \\ Maria Guadalupe Villarreal-Treviño', Guadalupe Elizabeth Morales-Martinez², \\ Yanko Norberto Mezquita-Hoyos ${ }^{3}$
}

${ }^{1}$ Cognitive Science Laboratory, Department of Psychology, Nuevo Leon Autonomous University (UANL), Monterrey, Mexico ${ }^{2}$ Cognitive Science Laboratory, Institute of Research on the University and Education, National Autonomous University of Mexico (UNAM, IISUE), Mexico City, Mexico

${ }^{3}$ Cognitive Science Laboratory, Department of Psychology, Yucatan Autonomous University (UADY), Merida, Mexico

Email: gemoramar@hotmail.com

How to cite this paper: Garza-Figueroa, K. A., Lopez-Ramirez, E. O., Villarreal-Treviño, M. G., Morales-Martinez, G. E., \& MezquitaHoyos, Y. N. (2016). Functional Judgment of Young Mexican Heterosexuals' Judgment towards Gay, Lesbian and Heterosexual Adoption. Psychology, 7, 1785-1795. http://dx.doi.org/10.4236/psych.2016.714166

Received: October 26, 2016

Accepted: December 2, 2016

Published: December 5, 2016

Copyright $\odot 2016$ by authors and Scientific Research Publishing Inc. This work is licensed under the Creative Commons Attribution International License (CC BY 4.0).

http://creativecommons.org/licenses/by/4.0/

\begin{abstract}
An information integration theory (IIT) study aimed to explore Mexican youngers' systematic thinking underlying judgment and attitudes toward heterosexuals, gays and lesbian's rights for adoption. Here, 126 heterosexuals were required to take a cognitive algebra study consisting of 36 experimental manipulated social scenarios, each describing different couple adoption situations. The participant's experimental task was to provide an acceptability judgment by using a scale. Results showed, acceptability judgment varying from moderately favorable to not favorable that was regulated by two different cognitive rules. A cluster of participants having the higher index of acceptability showed systematic thinking moderated for a summative cognitive rule whereas judgment from another group of participants with a lower index of acceptability was moderated by a multiplicative cognitive rule. In both cases, the most relevant factor to consider was the couple romantic relationship stability. Theoretical and methodological implications are discussed in this article.
\end{abstract}

\section{Keywords}

Adoption, Attitudes, Cognitive Algebra, Couples, Heterosexual, Gays, Lesbians

\section{Introduction}

Human development of a society is reflected in the degree of respect, type of attitudes and actions made to achieve maximum well-being of all the people who constitutes 
such a society. This is so, regardless of their race, religion or sexual status. Thus, discriminatory behaviors toward minority groups are in turn an indicator of a recoil to development and in many cases this discriminatory behavior leads to denial of human rights of people belonging to minority groups. For example, considering rights for a community "LGBTTIQ" (lesbian, gay, bisexual, transvestite, transsexual, transgender, intersex, queer), the exercise of their rights to form a family has faced legal barriers (see Downing, Richardson, Kinkler, \& Goldberg, 2009; Ollen \& Goldberg, 2015), and social constraints (Taka, Szalma, \& Bartus, 2016; Kimberly \& Moore, 2015), etc.

Regarding this, several authors (e.g., Clarke, 2001; in Costa, Almeida, Anselmo, Ferreira, Pereira, \& Leal, 2014) have suggested that discriminatory judgment and negative attitudes towards adoption by gay and lesbian couples is based on an immorality perception or parenting inadequacy valuation due to a possible negative impact of parent's sexuality preference over an adopted child development. This unfounded judgment (see Schneider \& Vecho, 2015) have created negative attitudes and social consequences to this social group (Rye \& Meaney, 2010; Crawford \& Solliday, 1996). Take for instance, the adoption process where gay parents report more incisive interviews and inadequate suggestions to adopt specific children groups (Ross, Epstein, Anderson, \& Eady, 2009), or longer periods of waiting for adoption (Goldberg, Downing, \& Sauck, 2007), among other setbacks.

Recently, a remarkable academic effort has emerged to understand the nature of attitudes toward adoption by gay and lesbian couples, as well as to establish its magnitude and direction through different samples (e.g., adoptive parents: Averett, Strong-Blakeney, Nalavany, \& Ryan, 2011; college students: Papadaki, Plotnikof, \& Papadaki, 2013; public and private adoption agencies: Brodzinsky, Patterson, \& Vaziri, 2002; Spivey, 2006; sexologists: Viozzi, Tripodi, Nimbi, Baiocco, \& Simonelli, 2016) and in different countries (e.g., Greece: Papadaki et al., 2013; Portugal: Gato \& Fontaine, 2016; USA; Brodzinsky et al., 2002; Brown, Ryan, \& Pushkal, 2007), using various instruments (e.g., scales: Costa Almeida, Anselmo, Ferreira, Pereira, \& Leal, 2014; questionnaires: Spivey, 2006).

In general, international studies indicate that attitudes towards adoption by same-sex couples may vary from a population to another, depending on certain circumstances like the participant's gender, sexual orientation of the couple, the adopted child gender (see Gato \& Fontaine, 2016; Crawford, McLeod, Zamboni, \& Jordan, 1999), sexual beliefs (Spivey, 2006), the emotional stability of parents, the parental competition and responsibility (Morse, McLaren, \& McLachlan, 2007). For instance, Spivey's study on adoption (2006) found after comparing samples' favorable attitudes toward adoption. Such that students' attitudes were more favorable than workers of adoption agencies. Contrary to this result, Gato and Fontaine (2016) observed that Portuguese University students have a more favorable opinion towards the adoption by heterosexual couples. Here, students considered that the heterosexual parents have more parenting competencies than same sex couples. In addition, Crawford et al. (1999), observed in their study that many psychologists in USA considered more suitable an adoption for a he- 
terosexual couple than for the same sex couples if a female child was the target for an adoption.

In summary, even when nowadays there is a tendency to a more positive attitude towards adoption regarding same sex couples, there still is a tremendous negative bias for this to happen (Morse, McLaren, \& McLachlan, 2007) and research is in demand to know what are the specific psychological factors and the way these factors interact to sustain this negative bias.

Here it is argued that by considering an information integration theory approach then cognitive algebra studies can be implemented to explore systematic interaction of relevant psychological factors interacting sustaining this appointed negative bias toward adoption regrading same sex couples. Briefly, this theoretical approach proposes that human mind not only dynamically selects environmental variables but it has also the capacity to transform these stimuli into its correspondent psychological values and in turn integrate this psychological data through cognitive operators into meaningful interpretations sustaining our intellect and judgment (Anderson, 1981, 1991, 1996).

From this theoretical point of view, attitudes toward adoption by the same sex couples have not been explored and no integration cognitive rule of relevant psychological factors (like, sexual preference, time of romantic relationship, etc.) has been specified up to now. Specific determination of such a cognitive rule empower researchers to determine the weight of a specific psychological factor to sustain a negative bias (attitude) to misjudgment or discriminatory prejudice. Thus, in order provide insights on the nature of systematic thinking regarding adoption by gay or lesbian couples the following IIT studies were carried on.

\section{Literature Review}

In recent years, the Mexican society has shown a greater opening to sexuality themes that for long time have been considered as a taboo topic. For instance, the city of Mexico, is the first city of Latin America to allow marriage among same-sex people. This legislative change opened the opportunity for same-sex couples to empower rights as heritage to obtain bank loans, inheritance, social security and the possibility of adopting children (Barría, 2009). In fact, the city of Mexico, was the first place in Mexico to provide legal adoption rights to gay couple (Cancino, 2010).

In despite of this remarkable changes on Mexican population attitudes toward gays and lesbians' rights, there is little research specifying the reasons for attitudinal changes toward adoption in this population (e.g., Papadak et al., 2013; Rye \& Meaney, 2010; Brown, Ryan \& Pushkal, 2007; Gibbons, Wilson \& Rufener, 2006; Averett, Strong-Blakeney, Nalavany \& Ryan, 2011; Monto \& Supinski, 2014; Carrera-Fernández, Lameiras-Fernández \& Rodríguez-Castro, 2014; Fernández \& Alarcón, 2015). Most of available documentation on this topic relies on personal reflections over gays and lesbians' rights to have a family (e.g., Bernheim, 2013; Adoption more open for gays and lesbians, 2003; Vélez, 2011) or they constitute reports and law articles (e.g., Barría, 2009; Cancino, 2010; Aranda, 2015; Cruz, 2015, Agencia de Gestión Urbana de la Ciudad de 
México, n.d.) or simple general opinions on the topic (e.g., APA, 2005; Conapred, 2010; Buil, García-Rubio, Lapastora, \& Rabasot, 2004). There is no formal research on cognitive integration processes regarding attitudes toward adoption by same-sex couples.

Thus, the current study aims to find cognitive algebra rules modulating these attitudinal processes by considering four sources of information to judgment formation describing attributes of a couple desiring to adopt a child, namely, sexual orientation, couple status and stability of couple's romantic relationship. The research method intended for this porpoise is described next.

\section{Method}

The experimental design considers 36 experimental conditions resulting from orthogonal combination of four main factors. A first factor "Sexual orientation" and three other factors listed as relevant predictors in the selection and performance of prospective adoptive parents (e.g., age of the couple: Ward, 1998, levels of marital adjustment: Calvo, Palmieri, Codamo, Scampoli, \& Bianco, 2015). Specifically, it is explored the effect of sexual orientation (heterosexual, gay, lesbian), the couple's civil state (married or free union), couple's relationship endurance (6 months to 5 years) and couple's stability (regularly stable, sporadic fights, unstable relationship). Thus, factor combination $(3 \times$ $2 \times 2 \times 3$ ) resulted in 36 experimental conditions which were used to build the instrument.

\subsection{Instruments}

Each of the 36 experimental conditions was represented by a social scenario. Thus, each scenario briefly described an adoption case containing information from one level of each factor. At the bottom part of each scenario there was a question about the level of acceptability regarding the adoption case. Here, participants had to answer by using an eleven-point scale (varying from 0 to 10) (A scenario example is presented in Appendix).

\subsection{Participants}

This study considered 125 young Mexicans from different cities of Mexico. The sample age range varied between 18 and 30 years old $(M=22, S D=2)$. In this sample $64 \%$ were women and the rest were single males who explicitly manifested as heterosexuals. Regarding religion, the sample consisted of 56\% Catholics, 9\% Christian, 24\% atheist and the rest subscribed to other religious beliefs. All of the participants enrolled voluntarily with no economic incentive.

\subsection{Procedure}

Verbal consent for participation in the study was obtained for each participant. Then they were presented with the instrument as well as with verbal instruction on how to proceed through the study. Practice scenarios were presented in order for participants get familiar with the study. After practice participants were required to read 36 scena- 
rios describing possible adoption cases by couples having different sexual preferences. The experimental task was to provide acceptability judgments for each presented scenario. The time required to complete the task varied between 40 to 50 minutes.

\section{Results}

A cluster analysis was carried on over participants' raw judgment scores (Euclidean distance, K-means) to determine if judgment regarding adoption by couples with specific sexual preference could be typified inside different groups. After cluster identification, a repeated measures ANOVA was carried on over each group judgment scores considering the $3 \times 2 \times 2 \times 3$ experimental design. The goal was look for evidence suggesting that experimental factor interaction provided data patterns modulated by cognitive algebraic rules.

\subsection{Analysis Cluster}

Two main significative different response patterns $\left(\eta^{2}=0.68\right)$ were identified among participants. A first cluster $(\mathrm{N}=95,76 \%)$ was conformed by participants having a moderately favorable acceptability toward adoption $(M=6, D E=3)$, no matter which couple's sexual preference was under scrutiny: heterosexual $(M=6)$, gay $(M=6)$ or lesbian $(M=6)$. This cluster was recognized as a moderately favorable judgment group. A second cluster $(\mathrm{N}=30,24 \%)$ was typified by people having the lowest index of acceptability toward adoption $(\mathrm{M}=3, \mathrm{DE}=3)$. In this last group participants showed a moderately not favorable attitude toward heterosexual parents $(M=5)$ and highly not favorable toward gay parenting $(M=1)$ or lesbian $(M=1)$. Thus, this cluster was entitled as the less favorable or conservative judgment cluster.

\subsection{ANOVA}

For each cluster a repeated measure ANOVA was carried on considering a 3 (sexual orientation) $\times 2$ (civil state) $\times 2$ (time of romantic relationship) $\times 3$ (romantic relationship stability) experimental design. Statistical significance was set to $p<0.001$.

At least three aspects can be noticed from the above data. First, in both clusters the most relevant factor relates to couples' relationship stability. Second, couples' sexual orientation was only relevant to low acceptability cluster. Here, adoption by gays ( $\mathrm{M}=$ 1.5) and lesbians $(M=1.4)$ was considered less acceptable than adoption by heterosexual couples $(M=5)$. Third, in the less favorable judgment cluster the civil state of a couple factor seemed more relevant than couples' years of relationship. This is not the case for the first Cluster.

Notice, that no significative interaction was obtained for the moderate acceptability group $\left(\eta^{2}=0.09\right)$ (Table 1, Figure 1$)$ whereas the low acceptability group shows a significative interaction among sexual preference and couple's relationship stability $\left(\eta^{2}=\right.$ 0.60) (Table 1, Figure 1). This suggests that each identified cluster (moderately favorable and low favorable) use a different cognitive rule to judge acceptability regarding adoption by couples with different sexual preferences. 
Table 1. ANOVA results for each cluster.

\begin{tabular}{|c|c|c|c|c|c|c|c|}
\hline Source & $\mathrm{df}$ & MS & $\mathrm{df}$ & MS & $\mathrm{F}$ & $\mathrm{p}$ & $\eta^{2}$ \\
\hline \multicolumn{8}{|c|}{ Cluster 1 "Moderately favorable judgment" } \\
\hline Sexual orientation (So) & 2 & 1.067 & 190 & 1.814 & 0.588 & ns & 0.006 \\
\hline Civil state $(\mathrm{Cs})^{*}$ & 1 & 121.711 & 95 & 5.502 & 22.119 & 0.001 & 0.188 \\
\hline Years of relationship $(\mathrm{Yr})^{*}$ & 1 & 198.208 & 95 & 5.516 & 35.927 & 0.001 & 0.274 \\
\hline Couple stability $(\text { Cst })^{*}$ & 2 & $14,663.93$ & 190 & 23.385 & 627.065 & 0.001 & 0.868 \\
\hline $\mathrm{So}^{*} \mathrm{Cs}$ & 2 & 4.639 & 190 & 1.438 & 3.225 & $n s$ & 0.032 \\
\hline $\mathrm{So}^{*} \mathrm{Yr}$ & 2 & 7.033 & 190 & 1.772 & 3.968 & $n s$ & 0.040 \\
\hline So ${ }^{*}$ Cst & 4 & 1.409 & 380 & 2.016 & 0.699 & $n s$ & 0.007 \\
\hline $\mathrm{Cs} * \mathrm{Yr}$ & 1 & 0.002 & 95 & 2.173 & 0.0009 & ns & 0.000 \\
\hline $\mathrm{Cs}{ }^{\star} \mathrm{Cst}$ & 2 & 5.749 & 190 & 2.470 & 2.327 & $n s$ & 0.023 \\
\hline $\mathrm{Yr}^{\star} \mathrm{Ep}^{\star}$ & 2 & 20.537 & 190 & 2.076 & 9.889 & 0.001 & 0.094 \\
\hline \multicolumn{8}{|c|}{ Cluster 2 "Conservative judgment or less favorable" } \\
\hline Sexual orientation $(\text { So })^{*}$ & 2 & 1460.92 & 58 & 22.864 & 63.894 & 0.001 & 0.687 \\
\hline Civil state $(\mathrm{Cs})^{*}$ & 1 & 103.292 & 29 & 6.355 & 16.251 & 0.001 & 0.359 \\
\hline Years of relationship $(\mathrm{Yr})^{*}$ & 1 & 83.333 & 29 & 7.572 & 11.004 & $n s$ & 0.275 \\
\hline Couple stability $(\text { Cst })^{*}$ & 2 & 576.519 & 58 & 6.513 & 88.508 & 0.001 & 0.753 \\
\hline $\mathrm{So}^{*} \mathrm{Cs}$ & 2 & 36.2731 & 58 & 2.730 & 13.286 & 0.001 & 0.314 \\
\hline So $*$ Yr & 2 & 11.786 & 58 & 3.085 & 3.819 & $n s$ & 0.116 \\
\hline So ${ }^{*} \mathrm{Cst}^{*}$ & 4 & 219.919 & 116 & 4.897 & 44.900 & 0.001 & 0.607 \\
\hline $\mathrm{Cs} * \mathrm{Yr}$ & 1 & 0.0148 & 29 & 2.802 & 0.005 & $n s$ & 0.000 \\
\hline $\mathrm{Cs}{ }^{*} \mathrm{Cst}$ & 2 & 16.312 & 58 & 3.139 & 5.195 & $n s$ & 0.151 \\
\hline $\mathrm{Yr}^{\star}{ }^{*} \mathrm{Cst}$ & 2 & 8.302 & 58 & 2.927 & 2.836 & $n s$ & 0.089 \\
\hline
\end{tabular}

a. Significance $p<0.001$.

Moreover, notice from Figure 1 that the group with higher acceptability towards adoption and sexual diversity (cluster 1 ) uses a summative cognitive to moderate judgment of acceptability whereas the second group (low acceptability) produces judgment of acceptability using a multiplicative cognitive algebraic rule.

\section{Discussion and Conclusion}

This study aimed to measure in a sample of young heterosexual acceptability judgments toward infant adoption by heterosexual, lesbian and gay couples. Here, a cluster analysis identified two different visions-moderate acceptance and not acceptable-underlying study participants' acceptance judgment. This oscillation in the sample's level of acceptance toward adoption is congruent with some sources of academic research (see introduction) where evidence suggested that even when there are some groups of people having a gradual increasing acceptance and motivation supporting adoption and 
the right to form by same sex preference minority groups there are people who clearly opposes this initiative. This last group represented in this study as the low acceptance group, significantly weighted more acceptable adoption by heterosexuals than by gays or lesbians (see Table 1 and Figure 1). This is interesting since it represents a ruled

Cluster 1
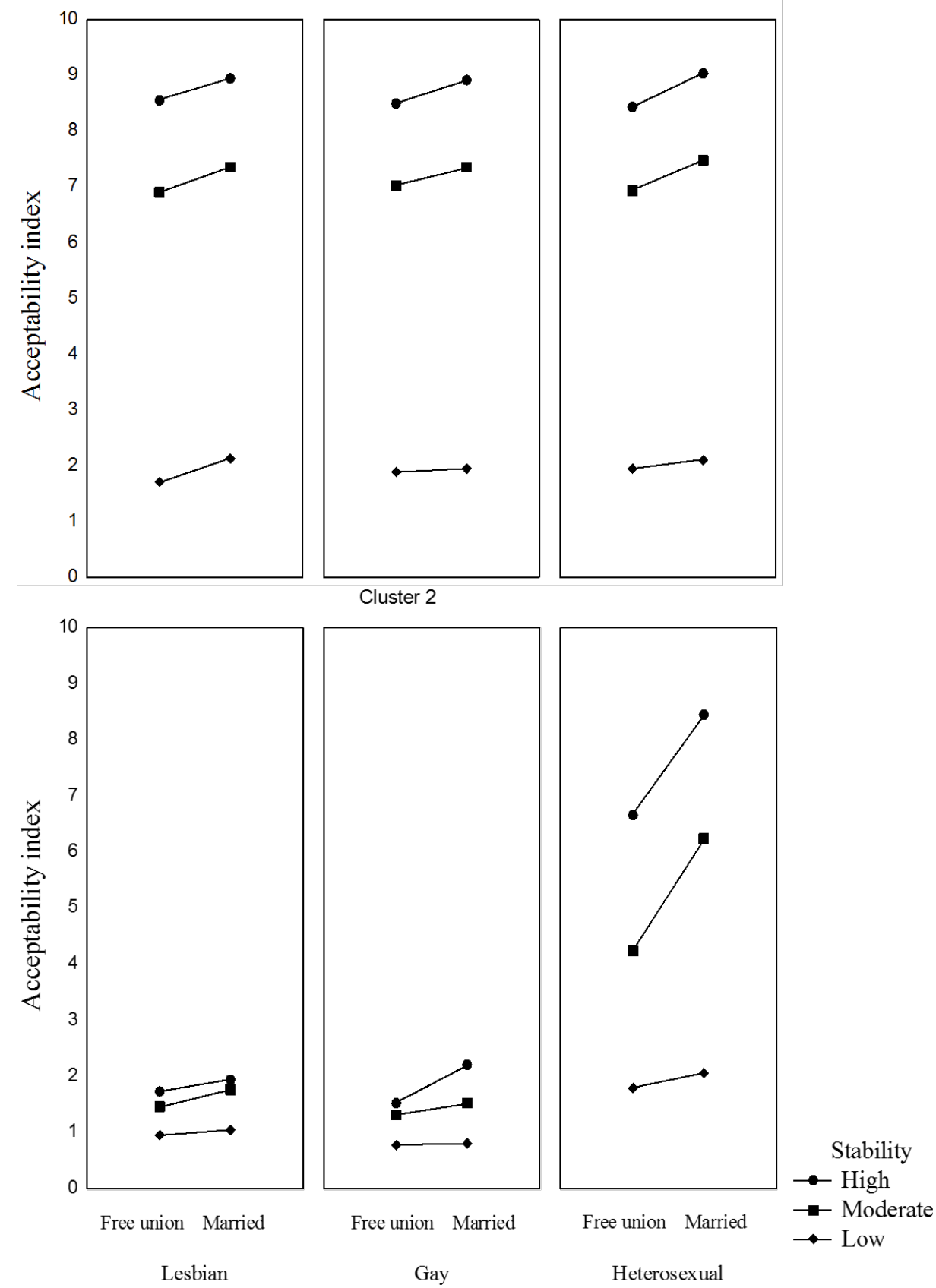

Figure 1. Interaction graph showing cognitive integration of study factors in both groups: Couples' relationship stability $\times$ couples' civil state and sexual orientation of a couple. The Top panel shows the data response pattern for the moderate acceptability group towards adoption whereas the bottom panel shows the low acceptability group's performance through experimental conditions. 
implicit negative bias towards a sexual preference of a minority group. Probably, this cluster presents judgment related to a conservative vision, since this group's judgments consider that when a couple satisfy a civil cannon like marriage, then couples are considered stable enough for adoption even if these couples had a long-term relationship.

A relevant aspect in this study was the different information integration cognitive rule shown by each group. This suggests that there is a possible different way to integrate information toward adoption depending on the level of acceptability under scrutiny. It is clear that more research is on demand to explore if the detected information integration mechanisms regarding acceptability toward adoption do indeed vary depending not only on attitude type (favorable not favorable) but also on sexual preference of participants (gay, lesbian, transgender, etc.).

Finally, it is worthy to emphasize the utility of using an information integration theory approach to continue the exploration of systematic thinking underlying attitudes toward human rights of the LGBTQ community. For instance, IIT academic efforts can be aimed to explore differences between and within heterosexual and LGBTQ communities to determine cognitive systematic thinking variations underlying modulating attitude and judgment formation towards LGBTQ's rights to sex, marriage and family formation.

\section{References}

Adoption More Open for Gays and Lesbians (2003). Magazine USA Today. https://www.questia.com/magazine/1G1-99849663/adoption-more-open-for-gays-and-lesbians

Agencia de Gestión Urbana de la Ciudad de México (n.d.). Adopción Homoparental [LGBT Adoption]. http://www.agu.cdmx.gob.mx/adopcion-homoparental/

American Psychiatric Association. (2005). Lesbian and Gay Parenting. APA: Author.

Anderson, N. H. (1981). Methods of Information Integration Theory. New York: Academic Press.

Anderson, N. H. (1991). Contributions to Information Integration Theory. Hillsdale, NJ: Erlbaum.

Anderson, N. H. (1996). A Functional Theory of Cognition. Mahwah, NJ: Erlbaum.

Aranda, J. (2015). Avala la Corte derecho de parejas gay a adoptar [The Court Endorses Gay Couples' Right to Adoption].

www.jornada.unam.mx/ultimas/2015/08/11/parejas-gay-y-heterosexuales-pueden-adoptar-det ermina-la-corte-623.html

Averett, P., Strong-Blakeney, A., Nalavany, B. A., \& Ryan, S. D. (2011). Adoptive Parents' Attitudes towards Gay and Lesbian Adoption. Journal of GLBT Family Studies, 7, 30-48.

https:/doi.org/10.1080/1550428X.2011.537211

Barría, C. (2009). México DF: Aprueban Matrimonio Gay [México DF: Gay Marriage Is Approved]. http://www.bbc.com/mundo/america_latina/2009/12/091221_2340_mexico_gay_gm.shtml?pri $\underline{\mathrm{nt}=1}$

Bernheim, G. (2013). Homosexual Marriage, Parenting, and Adoption. First Things. Journal of Religion \& Public Life.

https://www.firstthings.com/article/2013/03/homosexual-marriage-parenting-and-adoption 
Brodzinsky, D. M., Patterson, C. J., \& Vaziri, M. (2002). Adoption Agency Perspectives on Lesbian and Gay Prospective Parents: A National Study. Adoption Quarterly, 5, 5-23. https:/doi.org/10.1300/J145v05n03_02

Brown, D., Ryan, S., \& Pushkal, J. T. (2007). Initial Validation of the Open Adoption Scale: Measuring the Influence of Adoption Myths on Attitudes toward Open Adoption. Adoption Quarterly, 10, 179-196. https:/doi.org/10.1080/10926750802163246

Buil, E., García-Rubio, E., Lapastora, M., \& Rabasot, M. (2004) La adopción por homosexuales [Homosexuals and Adoption]. Anuario de Psicología Jurídica, 14, 81-98.

Calvo, V., Palmieri, A., Codamo, A., Scampoli, M. R., \& Bianco, F. (2015). Perceptions of Parental Bonding, Adult Attachment, and Marital Adjustment in Prospective Adoptive Parents. An Empirical Study in the Pre-Adoptive Period. Sexual and Relationship Therapy, 30, 419-432. https:/doi.org/10.1080/14681994.2014.1001355

Cancino, F. (2010). La Suprema Corte aprueba el derecho de adopción a matrimonios gay [Supreme Court Approves Gay Couples Adoption].

http://mexico.cnn.com/nacional/2010/08/16/la-suprema-corte-aprueba-el-derecho-deadopcio n-a-matrimonios-gay

Carrera-Fernández, M. V., Lameiras-Fernández, M., \& Rodríguez-Castro, Y. (2014) Spanish Adolescents' Attitudes toward Transpeople: Proposal and Validation of a Short Form of the Genderism and Transphobia Scale. Journal of Sex Research, 51, 654-666.

https:/doi.org/10.1080/00224499.2013.773577

Consejo Nacional para Prevenir la Discriminación (Conapred) (2010). Encuesta nacional sobre la discriminación en México [National Survey on Discrimination in Mexico]. http://www.conapred.org.mx/userfiles/files/Enadis-2010-RG-Accss-002.pdf

Costa, P. A., Almeida, R., Anselmo, C., Ferreira, A., Pereira, H., \& Leal, I. (2014). University Students' Attitudes toward Same-Sex Parenting and Gay and Lesbian Rights in Portugal. Journal of Homosexuality, 61, 1667-1686. https:/doi.org/10.1080/00918369.2014.951253

Crawford, I., \& Solliday, E. (1996). The Attitudes of Undergraduate College Students toward Gay Parenting. Journal of Homosexuality, 30, 63-77. https:/doi.org/10.1300/J082v30n04_04

Crawford, I., McLeod, A., Zamboni, B. D. \& Jordan, M. B. (1999). Psychologists' Attitudes toward Gay and Lesbian Parenting. Professional Psychology: Research and Practice, 30, 394-401. https:/doi.org/10.1037/0735-7028.30.4.394

Cruz, C. (2015). México se suma a 20 países que aprueban la adopción homosexual [Mexico Joins 20 Countries That Approve Homosexual Adoption].

http://www.latercera.com/noticia/mundo/2015/08/678-643147-9-mexico-se-suma-a-20-paisesque-aprueban-la-adopcion-homosexual.shtml

Downing, J., Richardson, H., Kinkler, L., \& Goldberg, A. (2009). Making the Decision: Factors Influencing Gay Men's Choice of an Adoption Path. Adoption Quarterly, 12, 247-271. https:/doi.org/10.1080/10926750903313310

Fernández, M., \& Alarcón, E. (2015) Adoption and Homosexual Parenting. Professionals' Attitudes in a Spanish Sample. Acción Psicológica, 12, 91-102. https:/doi.org/10.5944/ap.12.1.14269

Gato, J., \& Fontaine, A. M. (2016). Attitudes toward Adoption by Same-Sex Couples: Effects of Gender of the Participant, Sexual Orientation of the Couple, and Gender of the Child. Journal of GLBT Family Studies, 12, 46-67. https:/doi.org/10.1080/1550428X.2015.1049771

Gibbons, J. L., Wilson, S. L., \& Rufener, C. A. (2006). Gender Attitudes Mediate Gender Differences in Attitudes toward Adoption in Guatemala. Sex Roles, 54, 139-145.

https:/doi.org/10.1007/s11199-005-8875-0 
Goldberg, A. E., Downing, J. B., \& Sauck, C. C. (2007). Choices, Challenges, and Tensions: Perspectives of Lesbian Prospective Adoptive Parents. Adoption Quarterly, 10, 33-64. https:/doi.org/10.1300/J145v10n02_02

Kimberly, C., \& Moore, A. (2015). Attitudes to Practice: National Survey of Adoption Obstacles Faced by Gay and Lesbian Prospective Parents. Journal of Gay \& Lesbian Social Services, 27, 436-456. https:/doi.org/10.1080/10538720.2015.1085347

Monto, M. A., \& Supinski, J. (2014). Discomfort with Homosexuality: A New Measure Captures Differences in Attitudes toward Gay Men and Lesbians. Journal of Homosexuality, 61, 899916. https:/doi.org/10.1080/00918369.2014.870816

Morse, C. N., McLaren, S., \& McLachlan, A. J. (2007) The Attitudes of Australian Heterosexuals toward Same-Sex Parents. Journal of GLBT Family Studies, 3, 425-455. https:/doi.org/10.1300/J461v03n04_04

Ollen, E. W., \& Goldberg, A. E. (2015). Parent-Child Conversations about Legal Inequalities in Gay- and Lesbian-Parent Families in Florida. Journal of GLBT Family Studies, 365-385.

Papadaki, V., Plotnikof, K., \& Papadaki, E. (2013). Social Work Students' Attitudes towards Lesbians and Gay Men: The Case of the Social Work Department in Crete, Greece. Social Work Education, 32, 453-467. https:/doi.org/10.1080/02615479.2012.687371

Ross, L. E., Epstein, R., Anderson, S., \& Eady, A. (2009). Policy, Practice, and Personal Narratives: Experiences of LGBTQ People with Adoption in Ontario, Canada. Adoption Quarterly, 12, 272-293. https:/doi.org/10.1080/10926750903313302

Rye, B. J., \& Meaney, G. J. (2010). Self-Defense, Sexism, and Etiological Beliefs: Predictors of Attitudes toward Gay and Lesbian Adoption. Journal of GLBT Family Studies, 6, 1-24. https:/doi.org/10.1080/15504280903472485

Schneider, B., \& Vecho O. (2015). Le développement des enfants adoptés par des familles homoparentales: Une revue de la littérature. Neuropsychiatrie de l'Enfance et de l'Adolescence, 63, 401-412. https:/doi.org/10.1016/j.neurenf.2015.04.010

Spivey, C. A. (2006). Adoption by Same-Sex Couples. Journal of GLBT Family Studies, 2, 29-56. https:/doi.org/10.1300/J461v02n02_02

Taka, J., Szalma, I., \& Bartus, T. (2016). Social Attitudes toward Adoption by Same-Sex Couples in Europe. Archives of Sexual Behavior, 45, 1787-1798. https:/doi.org/10.1007/s10508-016-0691-9

Vélez, S. E. (2011). Familia, matrimonio y adopción: Algunas reflexiones en defensa del derecho de las parejas del mismo sexo a constituir familia y de los menores a tenerla [Family, Marriage and Adoption: Some Reflections on Defense the Right of Same-Sex Couples to form a Family and of Children to Have It]. Revista de Derecho, 126-159.

Viozzi, E., Tripodi, F., Nimbi, F. M., Baiocco, R., \& Simonelli, C. (2016). P-01-046 Sexologists Attitudes toward Same-Sex Marriage and Parenting. The Journal of Sexual Medicine, 13, S157. https:/doi.org/10.1016/j.jsxm.2016.03.199

Ward, M. (1998). The Impact of Adoption on the New Parents' Marriage. Adoption Quarterly, 2, 57-78. https:/doi.org/10.1300/J145v02n02_04 


\section{Appendix}

Edgar and Stephanie are a married couple since 5 years ago, and they are going through the process to adopt a baby. They do not fight frequently, have a good communication and they agree in most of the cases.

The adoption agency decided to authorize the baby custody

How much do you agree with this decision?

Nothing agree o------0-----0-----o-----0-----0-----0-----0-----o-----o-----o Completely agree.

Submit or recommend next manuscript to SCIRP and we will provide best service for you:

Accepting pre-submission inquiries through Email, Facebook, LinkedIn, Twitter, etc. A wide selection of journals (inclusive of 9 subjects, more than 200 journals)

Providing 24-hour high-quality service

User-friendly online submission system

Fair and swift peer-review system

Efficient typesetting and proofreading procedure

Display of the result of downloads and visits, as well as the number of cited articles

Maximum dissemination of your research work

Submit your manuscript at: http://papersubmission.scirp.org/

Or contact psych@scirp.org 